\title{
Positive and Negative Diaspora Governance in Context: From Public Diplomacy to Transnational Authoritarianism
}

Positive and Negative Diaspora Governance in Context: From Public Diplomacy to Transnational Authoritarianism, in Middle East Critique (with Bahar Baser) https://www.tandfonline.com/doi/abs/10.1080/19436149.2020.1770449?fbclid=IwAR0C5qetTHGWTnblQKoasCoC1bz2thR-20jUy2xEXsYuWSfCLW5VgtWVmM\&journalCode=ccri20

\section{BAHAR BASER $^{\mathrm{a}} \&$ AHMET ERDI OZTURK ${ }^{\mathrm{b}}$ \\ ${ }^{\mathrm{a}}$ Coventry University, UK $\quad{ }^{\mathrm{b}}$ London Metropolitan University, UK}

\begin{abstract}
The diaspora studies literature recently has indicated an expansion in state-led diaspora engagement initiatives and burgeoning diaspora governance institutions around the world. Home states have correlated concepts such as public diplomacy and soft power with these nascent incentives to cultivate and mobilize diasporas for state interests. Despite the interpretation of these developments as the expansion of citizenship rights for the diaspora and their systematic incorporation back into the home nation, some authors remain skeptical about the multifaceted motives behind such initiatives. Authoritarian states particularly employ diaspora governance as a mechanism to monitor and control diaspora groups, which home communities perceive as dissidents. Using Turkey and its recent diaspora governance policy as a case study, this article demonstrates that diaspora governance enables the state to create, depending on the context, potentially ideological and repressive transnational state apparatuses that can assume both positive and negative forms.
\end{abstract}

Key Words: Authoritarianism; Diaspora; Migration; Public Diplomacy, Turkey 
Recent decades have seen the recognition of diasporas as emerging non-state actors in the international arena with potency and leverage to act as agents of change. International NGOs and supranational organizations approach diaspora communities to act as bridges between home and host country policy-makers, and home and host country political actors themselves reach out for various reasons to diasporas as resources. ${ }^{1}$ Until recently, most diaspora research has focused on how the states in the Global North "receive" outsiders and has devoted limited scrutiny to the role of sending states in shaping opportunity structures abroad. ${ }^{2}$ Nascent studies indicate the rise of state-led diaspora engagement initiatives and the mushrooming of diaspora governance institutions around the world. ${ }^{3}$ This might originate from the migration-development nexus, ${ }^{4}$ the idea of enhancing the global competitiveness of the country in the knowledge-based economy ${ }^{5}$ and the desires of sending states to utilize the

Correspondence addresses: Bahar Baser, Coventry University. Centre for Trust, Peace and Social Relations, Cheetah Road, Coventry CV1 2TL, United Kingdom ; E-mail: ab8225@coventry.ac.uk. Ahmet Erdi Ozturk, London Metropolitan University, School of Social Science ; E-mail: e.ozturk@londonmet.ac.uk

1 Eva Østergaard-Nielsen (2003) The politics of migrants' transnational political practices, International Migration Review, 37(3), pp. 760-786; Elaine Lynn-EE Ho (2011) 'Claiming' the diaspora: Elite mobility, sending state strategies and the spatialities of citizenship, Progress in Human Geography, 35(6), pp. 757-772; Simon Turner \& Nauja Kleist (2013) Introduction: Agents of change? Staging and governing diasporas and the African state, African Studies, 72(2), pp. 192-206; Alenxandra Délano \& Alan Gamlen (2014) Comparing and theorizing state-diaspora relations, Political Geography, 41, pp. 43-53; Francesco Ragazzi (2014) A comparative analysis of diaspora policies, Political Geography, 41, pp. 74-89; Gerasimos Tsourapas (2015) Why do states develop multi-tier emigrant policies? Evidence from Egypt, Journal of Ethnic and Migration Studies, 41(13), pp. 2192-2214; Ahmet Erdi Ozturk \& Hakki Tas (2020) The Repertoire of Extraterritorial Repression: Diasporas and Home States, Migration Letters, 17(1), pp. 59-69.And Yehonatan Abramson (2017) Making a homeland, constructing a diaspora: The case of Taglit-Birthright Israel, Political Geography, 58, pp. 14-23.

${ }^{2}$ Laurie A. Brand (2006) Citizens abroad: Emigration and the state in the Middle East and North Africa, Vol. 23 (Cambridge: Cambridge University Press).

3 Asli S. Okyay (2015) Diaspora-making as a state-led project: Turkey's expansive diaspora strategy and its implications for emigrant and kin populations, $\mathrm{PhD}$ thesis, European University Institute, Florence, Italy; Hung Liu \& ElsVan Dongen (2016) China's diaspora policies as a new mode of transnational governance, Journal of Contemporary China, 25(102), pp. 805-821; Zeynep Yanasmayan \& Zeynep Kaşl1 (2019) Reading diasporic engagements through the lens of citizenship: Turkey as a test case, Political Geography, 70, pp. 24-33.

\footnotetext{
${ }^{4}$ Alan Gamlen (2008) Why engage diasporas? ESRC Centre on Migration, Policy and Society, Working Paper
} No. 63, University of Oxford. 
social, political and economic capital that diasporas accumulate abroad. ${ }^{6}$ Concepts such as public diplomacy ${ }^{7}$ or diaspora diplomacy ${ }^{8}$ have entwined with these recent state-led initiatives. Despite the interpretation of these developments as the expansion of citizenship rights for diasporas and their systematic incorporation back into the nation, some authors remain skeptical about the multifaceted motives behind such initiatives. For instance, prominent scholars such as Laurie Brand have argued that the formulation of diaspora policies seeks to "penetrate and surveil the community abroad as an extension of the authoritarian state apparatus. ${ }^{99}$ Recently, empirical analyses of various case studies have shown that diaspora governance is not a straightforward policy formulated by governments to keep up with globalization or neo-liberal trends but that the objectives of home states are multidimensional. For instance, SimonTurner's extensive study on the Rwandan diaspora revealed that while the homeland actors started treating the diaspora as agents of economic development or as unofficial ambassadors for the country, they also constructed diaspora engagement policies that aimed to suppress voices deemed political or security threats. ${ }^{10}$ Such ulterior motives clearly emphasize the ease with which soft policies of diaspora management accompany stringent politics of security, surveillance, and retribution. ${ }^{11}$

\footnotetext{
${ }^{5}$ Ho, 'Claiming' the Diaspora, pp. 757-772.

${ }^{6}$ Ragazzi, Comparative Analysis, pp. 74-89.

${ }^{7}$ Sebnem Koser Akçapar \& Damla Bayraktar Aksel (2017) Public Diplomacy through Diaspora Engagement: The Case of Turkey, Perceptions: Journal of International Affairs, 22(3), pp. 135-160.

8 Bhattiprolu Murti \& Rhonda. S. Zaharna (2014) India's Digital Diaspora Diplomacy: Operationalizing Collaborative Public Diplomacy Strategies for Social Media, Exchange: The Journal of Public Diplomacy, 5(1), p. 3. D. Stone \&, E. Douglas (2018) Advance diaspora diplomacy in a networked world, International Journal of Cultural Policy, 24(6), pp. 710-723.

${ }^{9}$ Laurie A. Brand (2002) States and their expatriates: Explaining the development of Tunisian and Moroccan emigration-related institutions. Working Paper (University of Southern California).

${ }^{10}$ Simon Turner (2013) Staging the Rwandan diaspora: The politics of performance, African Studies, 72(2), pp. 265-284.

${ }^{11}$ Ibid. p. 273.
} 
The literature argues that state-led diaspora policies can have multiple roles and varying impacts on different segments of the diaspora population. In this article, we build on this literature and discuss the negative and positive diaspora governance policies that sending states formulate to engage with their diasporas abroad. We selected Turkey as a case study, because it provides ample examples ranging from public diplomacy initiatives to transnational authoritarianism. ${ }^{12}$ A country such as Turkey, which has sent migrants to Europe and elsewhere in the world for more than five decades, undoubtedly constructed policies to deal with emigration. It is, with its current policy, "reclaiming" its diaspora while redefining who is a part of the nation and who can represent state interests abroad. ${ }^{13}$ Turkey concurrently is undergoing domestic transformation and changing the way it deals with its citizens abroad. It is consequently internationalizing power struggles and altering the state identity.

The AKP (Justice and Development Party) has transformed the country since it came to power in 2002. Trailing its first couple years of rule were extravagant expectations of democratic reform and prosperity. Ascension to the European Union (EU) was still a possibility, and the AKP shook off the Kemalist legacy by challenging the military and bureaucratic tutelage, then a norm rather than an exception in Turkey. ${ }^{14}$ However, the party shed its democratic tendencies as it consolidated power. The 2013 Gezi protests constituted a turning point for its democratic decline, and subsequent events including the collapse of the Turkish-Kurdish peace talks and the failed coup attempt in 2016 delivered for the country a total authoritarian crackdown. ${ }^{15}$ The transformation of the AKP influenced the conception of domestic and foreign policy priorities, including diaspora policy. Although the initial

\footnotetext{
${ }^{12}$ For a previous study on Turkey's negative and positive diaspora engagement from the perspective of citizenship, see Yanasmayan and Kasli Reading diasporic engagements, pp. 24-33

${ }^{13}$ We build on the concept of "claiming diaspora" from Ho Claiming' the diaspora.

${ }^{14}$ M. Hakan Yavuz Yavuz (ed.) (2006) The Emergence of a New Turkey: Islam, Democracy, and the AK Parti (Utah: University of Utah Press).

${ }^{15}$ Bahar Baser \& Ahmet Erdi Öztürk (2017) Authoritarian politics in Turkey: Elections, resistance and the AKP (London: Bloomsbury Publishing).
} 
objective was to utilize diaspora policy to foster a positive image of Turkey abroad using transnational actors and actions as public diplomacy and tools of soft power, ${ }^{16}$ political developments compelled the ruling party to shift its focus toward consolidating power. ${ }^{17} \mathrm{By}$ simultaneously forging negative and positive diaspora policy, the AKP created an intricate series of relationships with Turkish citizens and their relatives living abroad. ${ }^{18}$

Although Turkish domestic politics always have influenced Turkey's diaspora communities, we highlight a new trend in Turkey's engagement with its citizens and their descendants abroad. The establishment of the Office for Turks Abroad and Related Communities (YTB) and other state institutions testify to the fact that President Recep Tayyip Erdogan and consecutive AKP governments invested significantly in the potential of Turkish diasporas. Some interpret this as the empowerment of Turkey's diaspora communities abroad. ${ }^{19}$ However, the diaspora is notably situated in a space that forges competing narratives. ${ }^{20}$ In this article, we examine whether Turkey has a "one size fits all" policy or has formulated different policies to address competing diaspora narratives. Scrutinizing the nexus of the sending state and diaspora in detail gives us insight into "state resilience" in the international arena and the "new practices of sovereignty." 21 What motives and interests drive Turkey's recent interest in its diaspora? How does Turkey design its diaspora policy as a "spectacle to establish sovereignty" 22 in its populations living abroad?

\footnotetext{
${ }^{16}$ Yasar Aydin (2014) "The New Turkish Diaspora Policy - Its Aims, Their Limits and the Challenges for Associations of People of Turkish Origin and Decision-makers in Germany”, SWP Research Paper, accessed March 1, 2019.

${ }^{17}$ Bahar Baser (2017) Turkey’s Ever-Evolving Attitude-Shift Towards Engagement with Its Diaspora, in: Emigration and Diaspora Policies in the Age of Mobility, pp. 221-238 (Springer, Cham).

${ }^{18}$ Yanasmayan and Kasli Reading diasporic engagements, pp. 24-33

19 Can Unver (2013) Changing diaspora politics of Turkey and public diplomacy, Turkish Policy Quarterly, 12(1), p 183.

${ }^{20}$ Claudine Kuradusenge (2016) Denied Victimhood and Contested Narratives: The Case of Hutu Diaspora, Genocide Studies and Prevention: An International Journal, 10(2), p. 59.

${ }^{21}$ Laurie A. Brand (2006) Citizens abroad: Emigration and the state in the Middle East and North Africa, Vol. 23 (Cambridge: Cambridge University Press).

${ }^{22}$ S. Turner (2013), Staging the Rwandan diaspora, p. 266.
} 
We demonstrate that Turkey employed its new diaspora policy and the nexus of institutions created as a result of sometimes discursive and sometimes repressive transnational state apparatuses $^{23}$ to cultivate, supervise, and command the diaspora. Some aspects of these policies benefited all members of the diaspora, while others privileged certain segments of the community but disadvantaged or oppressed others.

\section{State-led Diaspora Engagement: Diaspora-building and Governance}

Scholars in recent decades have sought to conceptualize the interactions of sending states with their diasporas. Recently, however, the institutionalization of these relationships has begun to gather broader attention. Laurie Brand $^{24}$ argued that still characterizing the international system is the presence and interaction of sovereign states. However, these states' acknowledging the importance of their diasporas and formulating multifaceted policies for engagement became the focus of scrutiny, as it clearly demonstrated that nation states were not challenged by but instead adapted to globalization. Concepts such as "diaspora management" or "diaspora governance" became popular to define state-driven initiatives for forming policies to strengthen links with citizens and their descendants abroad as well as attracting certain segments of this population back to the homeland. ${ }^{25}$ Authors such as Elaine Lynn-Ee Ho, ${ }^{26}$ however, prefer concepts such as "diaspora strategies" to underline the selectivity of these policies and refer to how home states mobilize elite migrants while

\footnotetext{
${ }^{23}$ We borrow these concepts from Louis Althusser (2006) and apply them to the Turkish context from the angle of diaspora governance. Repressive state apparatuses (RSA) such as government, courts, and police are implements to suppress the masses through violent and non-violent means. Ideological state apparatuses (ISA) such as education, media, church, and mosques also disseminate the ideology of the ruling class in multifaceted ways. We argue that the institutions and organisations of which the diaspora governance policy comprises are also state apparatuses that employ RSA and ISA as transnational strategies to control diaspora populations.

${ }^{24}$ Laurie A. Brand (2017) State, citizenship, and diaspora: The cases of Jordan and Lebanon, Working Paper No. 146 (University of California, San Diego), p.1.

${ }^{25}$ Harris Mylonas (2013) The politics of diaspora management in the republic of Korea, The Asian Institute for Policy Studies, 81, pp. 1-12.

${ }^{26}$ Ho, Claiming' the diaspora, pp. 757-772.
} 
neglecting others, based on their utility for state interests and to enhance the global competitiveness of the homeland.

State-led diaspora engagement may originate from economic, political, or social motives ${ }^{27}$ and includes introducing rights such as expatriate voting, facilitating bureaucratic issues with home country policy-makers, and digitizing consulates and embassies for ease of access. These policies usually are multifaceted and encompass both symbolic and bureaucratic changes ${ }^{28}$ with varying motives, such as cultivating or recognizing the diaspora. For instance, some states such as Morocco or Jordan perceive their citizens abroad as "exploitable resources" rather than simply citizens, and economic considerations are pivotal in the formulation of state-led diaspora engagement policies. ${ }^{29}$ Lebanon launched a state initiative to interact with Lebanese communities outside its borders and established a separate Ministry of Expatriates after the end of the civil war. According to Brand, this institution was created as an imperative tool for the organization of relations with those who remained and those who fled, crafting a new authority to deal with arranging remittances from diasporas. Also salient in this context are the changing perceptions about emigration. For instance, Nicole Hirt and Saleh Mohammad ${ }^{30}$ show that in the Eritrean case the government initially attempted to punish emigrants but gradually shifted toward a pragmatic understanding and began to perceive members of the diaspora as an additional source of tax revenue. Beyond economic motives, some states may engage with their diaspora for political purposes such as nation-building or for lobbying host country governments in the interests of their home

\footnotetext{
${ }^{27}$ Gamlen, Why engage diasporas, p.3.

${ }^{28}$ Peggy Levitt, \& Rafael De la Dehesa (2003) Transnational migration and the redefinition of the state: Variations and explanations, Ethnic and racial studies, 26(4), pp. 587-611.

${ }^{29}$ Brand, States and their expatriates. Brand, State, citizenship, and diaspora.

${ }^{30}$ Nicole Hirt \&, Abdulkader Saleh Mohammad (2018) By way of patriotism, coercion, or instrumentalization: how the Eritrean regime makes use of the diaspora to stabilize its rule, Globalizations, 15(2), pp. 232-247.
} 
country. ${ }^{31}$ Many states also visibly associate diaspora governance with nation-branding ${ }^{32}$ and public diplomacy. ${ }^{33}$ Formulating a nexus of institutions to embrace populations abroad could bolster a nation's image while creating a soft power tool for home states to promote their interests by subcontracting certain roles to diaspora members as brand ambassadors of the state. ${ }^{34}$ Nation branding is strongly associated with nation-building, and states can instrumentalize diaspora policies to further state legitimacy both for domestic populations and the international audience. ${ }^{35}$ State-led diaspora initiatives therefore often can morph into propaganda machines for the ruling elites. ${ }^{36}$ Diasporas earn from these policies the "opportunity to rejoin the national community." ${ }^{37}$ However, do diaspora governance policies embrace all citizens and their descendants living abroad? As Harris Mylonas ${ }^{38}$ demonstrates, a state might adapt various policies to control and manage their diaspora, ranging from neglecting them completely to neglecting specific communities but not others to strategically keeping abroad or favoring certain groups.

Other alternative explanations also highlight the complexity of diaspora governance. According to Turner, ${ }^{39}$ states may "stage" their diaspora in the sense of creating a specific positive image for themselves. He demonstrates that the Rwandan state, for instance, utilizes its diaspora policy to create national unity and reconciliation for a new Rwanda. Members of the diaspora abroad are portrayed as agents of development and a source of skill and

\footnotetext{
${ }^{31}$ Østergaard-Nielsen, The politics of migrants', pp. 760-786.

${ }^{32}$ Ying Fan (2006) Branding the nation: What is being branded? Journal of vacation marketing, 12(1), pp. 5-14.

${ }^{33}$ Rhea Abraham (2012) India and its Diaspora in the Arab Gulf Countries: Tapping into Effective 'Soft Power' and Related Public Diplomacy, Diaspora Studies, 5(2), pp. 124-146.

${ }^{34}$ Gerasimos Tsourapas (2018) Authoritarian emigration states: Soft power and cross-border mobility in the Middle East, International Political Science Review, 39(3), pp. 400-416.

${ }^{35}$ Michael Barr (2012) Nation branding as nation building: China's image campaign, East Asia, 29(1), pp. 8194.

${ }^{36}$ Hongmei Li (2012) The Chinese Diaspora and China's Public Diplomacy: Contentious Politics for the Beijing Olympic Float, International Journal of Communication, 6, p. 35.

${ }^{37}$ Brand, Authoritarian states and voting from abroad p. 81.

${ }^{38}$ H. Mylonas, The politics of diaspora management, pp. 1-12.

${ }^{39}$ Turner, Staging the Rwandan diaspora, p. 265.
} 
knowledge, playing the role of ambassadors for Rwanda. Turner ${ }^{40}$ makes an intriguing point , stating: "The audience here is not only the diaspora, but also Rwandans inside Rwanda as well as the international community. In the meanwhile, the diaspora is categorized by the state into three categories: a positive diaspora that supports the state; a skeptical diaspora whose members may be converted; and a hostile diaspora beyond reach." The diaspora narrative that the state formulates demarcates the boundaries of whom the definition of the nation will incorporate and who will be considered a member of this national society. ${ }^{41}$ The question of who is deemed a "national hero" or "traitor" then depends on how the home state "stages" the diaspora. ${ }^{42}$

\section{Transnational Authoritarianism}

As Turner argues, the literature on neo-liberal interests in engaging diasporas typically ignores political clusters and reduces transnational interactions between the state and the citizens abroad to a "technical question of development." 43 However, despite the positive sides of state-driven policies, politics saturates "policies of engagement" and nascent evidence suggests that these policies also can prompt the transnational oppression of communities. States use the methods of accepting diasporas as a means of regulating and containing the diaspora. ${ }^{44}$ For instance, Hirt and Saleh Mohammad ${ }^{45}$ dub this phenomenon “transnational authoritarian rule," David Lewis ${ }^{46}$ calls it "extraterritorial security practices," Dana Moss ${ }^{47}$ defines it as "transnational repression," and Emma Lundgren Jorum ${ }^{48}$ opts for

\footnotetext{
${ }^{40}$ Ibid., 266.

${ }^{41}$ Gamlen, Why engage diasporas p. 3.

${ }^{42}$ Turner and Kleist, Introduction: Agents of change, pp. 198-199.

${ }^{43}$ Turner, Staging the Rwandan diaspora, p. 266.

${ }^{44}$ Turner and Kleist, Introduction: Agents of change, p. 200.

${ }^{45}$ N. Hirt \&, A. Saleh Mohammad By way of patriotism, coercion, or instrumentalization, pp. 232-247.

${ }^{46}$ David Lewis. (2015) "Illiberal Spaces:" Uzbekistan's extraterritorial security practices and the spatial politics of contemporary authoritarianism, Nationalities Papers, 43(1), pp. 140-159.

${ }^{47}$ Dana Moss (2016) Transnational repression, diaspora mobilization, and the case of the Arab Spring, Social Problems, 63(4), pp. 480-490.
} 
the definition of "homeland repression across borders." Considering that diasporas usually comprise conflict-spawned groups who fled their homeland justifiably, it comes as no surprise that many countries from the Global South that formulate neo-liberal diaspora engagement policies today are hybrid or purely authoritarian regimes, sometimes establishing the façade of democratic elections. Lewis ${ }^{49}$ convincingly argues: "The spatial politics of authoritarian regimes frequently spill over into transnational space." Therefore, "a territorial conception of authoritarianism falls short in explaining the continuity of autocratic rule in the area of globalization." 50

Certain hierarchies among populations also ought to be considered in this context. States might govern diasporas by categorizing them as good or bad, useful or useless, or asset or threat. They might create "supportive diasporas" by mobilizing state resources to shape and reconfigure the diasporic space while simultaneously curbing other diaspora voices that do not fit their interest. ${ }^{51}$ For instance, Mylonas claims that some members of the Korean diaspora could be deemed more pure-blooded than others, thus creating internal ethnic hierarchies. ${ }^{52}$ Home states therefore produce positive and negative diaspora engagement policies,${ }^{53}$ sometimes concurrently. They also may divide diaspora groups into undesired and desired populations. ${ }^{54}$ These categorizations rely on the ideology that the state aims to reflect in diaspora governance policy. Loyalty to the current regime then becomes the partition between good citizens and traitors. In the context of Eritrea, "accusing the government, which is inseparably linked to the people, is perceived as an insult of every single Eritrean

\footnotetext{
${ }^{48}$ Emma Lundgren Jorum (2015) Repression across borders: homeland response to anti-regime mobilization among Syrians in Sweden, Diaspora Studies, 8(2), pp. 104-119.

${ }^{49}$ D Lewis. Illiberal Spaces.

${ }^{50}$ Hirt and Saleh Mohammad By way of patriotism, coercion, or instrumentalization p.8.

${ }^{51}$ Turner, Staging the Rwandan diaspora, p. 266.

${ }_{53}$ Mylonas, The politics of diaspora management, pp.7-8.

${ }^{53}$ Turner, Staging the Rwandan diaspora, p. 266. Jorum, Repression across borders p. 107.

${ }^{54}$ Turner and Kleist, Introduction: Agents of change, p. 203.
} 
national," and diaspora members who refuse to comply with government policies are deemed traitors. ${ }^{55}$ Hirt and Saleh Mohammad also specify the coerced obligations of the Eritrean diaspora to contribute financially to their homeland and to legitimize the regime by supporting its policies. ${ }^{56}$ Jorum's research demonstrates that Syrian authorities engaged in purely repressive measures against members of the Syrian diaspora in Sweden who left the refugee community and were in the opposition, prompting perpetual feelings of insecurity. ${ }^{57}$ Meanwhile, Lewis' study of Uzbekistani diaspora policy clearly evinced: “An authoritarian state can use extraterritorial security practices to maintain regime security, by extending the scale of domestic political controls across borders into transnational spaces occupied by diasporic and exile communities." ${ }^{, 58}$ Another example of negative diaspora engagement is Rwanda's efforts to suppress the dissident diaspora, which it perceives as a hostile political and security threat. Rwandan authorities consider these dissidents enemies in the national narrative, favor other groups in the diaspora, and create a separate supportive or developmental diaspora. ${ }^{59}$

The distinction between good and bad diasporas transcends the rhetoric of the state. The monitoring and surveillance of diaspora dissidents is common among home-states, especially those with authoritarian regimes. ${ }^{60}$ Many authoritarian states perceive their migrant communities and diasporas, empowered by globalization and modern technologies of communication, as potential threats and they consider this international environment of information difficult to monitor and regulate. ${ }^{61}$ It becomes vital for home states to protect the

\footnotetext{
${ }^{55}$ Hirt and Saleh Mohammad, By way of patriotism, coercion, or instrumentalization p.8.

${ }^{56}$ Ibid. p. 3.

${ }^{57}$ Jorum, Repression across borders p.108.

${ }^{58}$ Lewis, Illiberal Spaces p. 141.

${ }^{59}$ Turner Staging the Rwandan diaspora, p. 265.

${ }^{60}$ Marlies Glasius (2018) Extraterritorial authoritarian practices: a framework, Globalizations, 15(2), pp. 179197.

${ }^{61}$ Lewis, Illiberal Spaces p. 141.
} 
image of the country and the nation abroad. Morocco, for instance, established institutions to monitor and control diaspora affairs, and these were "in large part an extension of the Moroccan state's repressive domestic policy." ${ }^{2}$ Although these repressive policies directly impact the lives of diaspora members, they remain unnoticed among the host society and policy-makers. ${ }^{63}$ Alexander Cooley and John Heathershaw's book, Dictators without Borders, is an excellent resource for understanding the reach of dictatorial states to individuals exiled internationally and the foreign implementation of domestic policies. ${ }^{64}$ Their activities include threatening relatives back home, surveillance and monitoring, kidnapping, and even assassination. Jorum indicates that, according to the Swedish Intelligence Service (SAPO), about 20 state security services engage in illegal intelligence activity, infiltrating oppositional movements, and employing various threats to intimidate and prosecute dissidents on Swedish soil:

Some have embassy or trade office staff dedicated solely mapping oppositional groups and their activities. Some have agents placed at national airline offices and press agencies or us 'false refugees' to infiltrate and report on oppositional organizations in Sweden. Threats, often directed at family members still in the state of origin, are the most common way these states use to silence dissidents in Sweden. ${ }^{65}$

The Syrian case is not the only example, as other states for decades have used a variety of measures, including assassinations and kidnappings: Yugoslav authorities employed them against anti-communist groups; Iran targeted political opponents in the

\footnotetext{
${ }^{62}$ Brand, States and their expatriates.

${ }^{63}$ Jorum Repression across borders, p. 105.

${ }^{64}$ Alexander Cooley \& John Heathershaw (2017) Dictators without borders: Power and money in Central Asia (Connecticut: Yale University Press).

${ }^{65}$ Jorum, Repression across borders, p. 107.
} 
diaspora; and the USSR constantly monitored diaspora organizations. ${ }^{66}$ Today, states such as China, Eritrea, Iran, Kazakhstan and Rwanda target dissidents abroad by monitoring, conducting intelligence-gathering with help from loyal diaspora organizations, and requesting extraditions through INTERPOL. ${ }^{67}$ Scotland Yard, for instance, warned Rwandan citizens that they were not safe from assassination attempts. ${ }^{68}$ These actions are no doubt part of a state-making process that reinforces sovereignty ${ }^{69}$ and controls loyalty and dissent in the extraterritorial context for governance. Researchers have not yet scrutinized adequately the issue of how host states answer to such trans-border practices.

\section{Turkey's Diaspora Policy under the AKP: Reclaiming the Diaspora}

The number of Turkish citizens currently living abroad exceeds 6.5 million, of which 5.5 million reside in Western Europe. ${ }^{70}$ Although Turkey has been a migrant-sending nation for more than 50 years, only in the last decade-under the consecutive reign of AKP governments - has the word diaspora become a buzzword for politicians. ${ }^{71}$ In the era of rising state-led diaspora engagement policies, Turkey also became a pioneer in formulating policies to cultivate and manage its populations abroad as part of the ruling party's new domestic and foreign policy agenda. ${ }^{72}$ Turkey undoubtedly pursued transnational policies with Turkish migrants who migrated due to bilateral agreements with European countries starting in the 1950s. However, homeland-diaspora relations under AKP rule became a priority for policymakers, as the emerging nexus of institutions and other semi- and non-state organizations regulated relations between Turkey and its disapora. The paramount institution in this context is the Presidency for Turks Abroad and Related Communities (YTB), established in 2010.

\footnotetext{
${ }^{66}$ Lewis, Illiberal Spaces p. 141.

${ }^{67}$ Turner, Staging the Rwandan diaspora, p. 267.

${ }^{68}$ Ibid. 277.

${ }^{69}$ Ibid. 275.

${ }^{70} \mathrm{http}: / /$ www.mfa.gov.tr/the-expatriate-turkish-citizens.en.mfa Accessed 3 June 2019.

${ }_{71}$ Akcapar and Aksel, Public Diplomacy through Diaspora Engagement, p. 138.

${ }^{72}$ Baser, Turkey's Ever-Evolving Attitude-Shift Towards Engagement with Its Diaspora.
} 
Other organizations include the Yunus Emre Institutes, TIKA (Turkish Cooperation and Coordination Agency), DEIK (Foreign Economic Relations Board), Public Diplomacy Coordinator under the Prime Ministry, ${ }^{73}$ and the international branches of the Diyanet. ${ }^{74}$ The motives for each initiative varies. As Sebnem Koser Akcapar and Damla Bayraktar Aksel argue, upon assuming control in the early 2000s, the AKP government "needed a Turkish diaspora to refurbish the image of Turkey and to boost the stale EU membership agenda. ${ }^{75}$ It realized that the diaspora could be used in both ways: As a tool for 'soft power' and as an instrument to support the government's agenda." Other political, economic, and cultural incentives abounded. ${ }^{76}$ For example, the AKP wanted to forge ties with Turkish business networks abroad to enhance its economic outreach, to strengthen its political standing in the international arena, and to maintain intact cultural and religious ties with its nationals living abroad. Contrary to previous state policies that neglected the diaspora's agency and potential to contribute to state interests, the AKP reclaimed the Turkish diaspora and invested considerable time and energy to strengthen ties, build bridges, and sustain these relationships by institutionalizing networks. ${ }^{77}$

The activities and services that the YTB and other institutions provide fit into three categories: Services that benefit all Turkish citizens and their descendants; services that benefit only loyalist groups; and services that criminalize and repress others. The first category encompasses the introduction of expatriate voting rights, improved services at diplomatic missions, the facilitation of bureaucratic matters online, and policies related to pensions and taxes. The YTB significantly invested in ameliorating services abroad toward

\footnotetext{
${ }^{73}$ For more information on Turkey's Public Diplomacy Coordinator see: https://kdk.gov.tr/. Accessed 3 June 2019.

${ }^{74}$ Aydin, The New Turkish Diaspora Policy.

${ }^{75}$ Akcapar and Aksel, Public Diplomacy through Diaspora Engagement, p. 138

${ }^{76}$ Mencutek and Baser, Mobilizing Diasporas, pp. 86-105.

${ }^{77}$ Baser, Turkey's Ever-Evolving Attitude-Shift Towards Engagement with Its Diaspora.
} 
diaspora members, something that had long been a demand from the diaspora. ${ }^{78}$ Moreover, the YTB dedicated time and money in researching Islamophobia and xenophobia and published reports and information about racist attacks against Turkish populations abroad. Monitoring the well-being of Turkish citizens, especially in Europe, enable it to broadcast the impression of expansive extra-territorial outreach. The YTB also funds numerous $\mathrm{PhD}$ and master's thesis on topics pertaining to the Turkish diaspora and provides scholarships to foreign students and diaspora members to study in Turkey.

Secondly, Turkey created civil society organizations with organic ties to state authorities. The most visible of these is the UID (Union of International Democrats), which operates in Europe through numerous branches. The YTB and other organizations collaborated selectively with these diaspora organizations and declared them the symbolic ambassadors $^{79}$ who can advance Turkish interests abroad. The YTB has organized numerous activities in Europe and beyond in collaboration with diaspora organizations loyal to the AKP and its vision. It lobbied host country governments, organized counter-protests and activities in the case of dissident diaspora mobilization, and engaged in versatile activities aimed both at cultivating a vigorous and loyal diaspora and creating a favorable and potent image of Turkey in Europe. While these policies constituted a large part of creating a transnational Turkish Brand, the nexus of institutions and networks also were used to suppress groups of dissidents who could obstruct these initiatives. Therefore, as in examples such as Rwanda or Eritrea, diaspora governance policy bolstered certain groups in the diaspora to instill a positive global image while also transforming the transnational space into a battleground for Turkey's domestic disputes and ambitions.

\footnotetext{
${ }^{78}$ Mencutek and Baser, Mobilizing Diasporas, pp. 86-105

${ }^{79}$ Akcapar and Aksel, Public Diplomacy through Diaspora Engagement, p. 138
} 


\section{Transnationalizing the Turkish Brand: Soft power and public diplomacy in diaspora} spaces

While formulating diaspora engagement policy, Turkey needed to understand what Turkish diaspora was and then act according to this definition. ${ }^{80}$ Turkey's diaspora policy quickly morphed into diaspora governance a la Turca, in that state officials redefined the very essence of the concept of diaspora according to the new outlook of the AKP. In 2011, former prime minister and foreign minister Ahmet Davutoglu, who was a mastermind of Turkish foreign and diaspora policies, made the following remark:

We are changing the term of diaspora. We primarily change its content; what it contains. We conceive as our own diaspora not only our citizens living abroad, but also all kin communities that had been together with us in the past. The first orbit is our citizens abroad. Just outside that is the orbit of Albanians, Bosniaks, Circassians, Caucasians... Azeri people, all Turkic Republics are in the second orbit. The third orbit is composed of everyone who emigrated from these territories in some way and then lost their citizenship. ${ }^{81}$

This definition then expanded to incorporate Muslim populations around the world, including Palestinians, Rohingya, and Somali. ${ }^{82}$ The policy agenda specifically targeted the Middle East, Africa, and the Balkans as potential venues of influence. As a part of public diplomacy strategy, the concept of diaspora has found a comprehensive use that includes geographies where no sizeable Turkish diaspora exists yet exist as an area of priority on the AKP foreign

\footnotetext{
${ }^{80}$ Firat Yaldız (2019) A Critical Approach to the Term Turkish Diaspora: Is there 'the' Turkish Diaspora? Bilig, (91), pp. 53-80.

${ }^{81}$ Cited in, Asli Selin. Okyay (2015) Diaspora-making as a state-led project: Turkey's expansive diaspora strategy and its implications for emigrant and kin populations, $\mathrm{PhD}$ thesis, European University Institute. P. 183.

${ }^{82}$ Yaldiz, A Critical Approach to the Term Turkish Diaspora p. 64.
} 
policy agenda. Expressions such as "Ummah geography", "Ottoman residues", and "Islamic World" entered the vocabular of diaspora-related institutions in Turkey. ${ }^{83}$ By formulating such a wide policy, the AKP would have managed to insert influence, deploy its disputable and relatively ambivalent soft power in Europe through the Turkish diaspora, and mobilize wherever else included the so-called Global Ummah. ${ }^{84}$ For example, despite the limited number of Somalian diaspora members in Turkey, the 3rd International Somali Global Diaspora Conference was held in Istanbul under the guidance of Turkey's transnational state apparatuses. This was also an output of Turkey's ambition to be the "patrol of the Global Ummah". This strategy also aimed to transnationalize a new brand for Turkey that would be more inclusive, active, and engaging in the international arena under the AKP compared to its predecessors. For Turkish citizens around the world, this would demonstrate the extent of their home state's power to care for them despite the distance and that they are part of the Turkish nation - an inseparable component of the Turkish national identity and psyche. The AKP envisaged that re-embracing kin and diaspora would not only make Turkey stronger but also harness prestige in the international arena. Thus, becomes valid the argument that Turkey managed to transform its diaspora policies into "transnational state spectacles" 85 and stage a new ideological outlook that the ruling elites pursue.

As the AKP has transformed Turkey and Turkish society, it became a priority to create and sell to the masses a national narrative. Not only the "new Turkish story" but also the novel vision of the AKP must be communicated and promoted to its international audience - the diaspora Turks. The regime change that is slowly but steadfastly materializing in Turkey, for its survival and ability to withstand dissent, must engender a narrative that that

\footnotetext{
${ }^{83}$ Ibid, p. 65.

${ }^{84}$ Ahmet Erdi Öztürk \& Semiha Sözeri (2018) Diyanet as a Turkish foreign policy tool: Evidence from the Netherlands and Bulgaria, Politics and Religion, 11(3), pp. 624-648.

${ }^{85}$ Turner, Staging the Rwandan diaspora, p. 269.
} 
the domestic population and diaspora appreciate. For the perpetuity of the new regime in Turkey, nation-branding ultimately becomes a practice that unavoidably addresses loyal citizens, who then intricately, legitimately, and extensively bear the image of that nation to broader audiences. In other words, the new brand needs "brand ambassadors" or "new public diplomats $" 86$ who will help the Turkish state sustain its sovereignty in the international arena. The diaspora policy therefore became a useful instrument for the government, and its institutions transformed into transnational state apparatuses that can function to spread the ideology of the ruling class.

Turkey's diaspora strategy carefully took shape after diplomats, politicians, and experts examined a variety of cases from around the world. DEIK for instance published a strategy report that drew from the examples of Israel, Armenia, India, and Ireland. The report focused on issues such as increasing the lobbying potential of diasporas, erecting bridges between Turkish diaspora organizations, integrating second-generation diaspora members into nation-building practices, supporting integration but preventing assimilation, forging relations with other ethnic and religious diaspora groups, and globally disseminating Turkish cultural norms. One interesting recommendation by DEIK pertained to engaging with propaganda against Turkey; experts suggested that the Turkish diaspora engage with policymakers rather than dissident diasporas that create propaganda and reveal a conciliatory rather than fanatic or intransigent attitude. Some of these principles remained intact for the last decade, while others have faded due to the political climate and shifting priorities in Turkey. Turkish policy-makers have combined a lessons-learnt approach from other cases with Turkey's own domestic dynamics — increasing the role of Islam, Neo-ottoman vision, and political polarization - and created a highly functioning state apparatus useful for both

\footnotetext{
${ }^{86}$ Unver, Changing diaspora politics of Turkey p. 188.
} 
ideological dissemination and repression when necessary. It is, however, vulnerable to political shifts in Turkey, as its continuation relies on the political success of the AKP.

\section{Transnational Authoritarianism: Monitoring and Surveillance}

Although Turkey's public diplomacy and soft power efforts through diaspora policy appeared successful in various African countries and the Balkans, diaspora strategies quickly backfired in Europe for assorted reasons. Turkey made vast investments in governmental and nongovernmental organizations in Europe to further the AKP's agenda abroad. Besides lobbying, mobilizing civil society and diaspora organizations, and coordinating educational and cultural events, transnational state apparatuses have been used to monitor and control dissident diaspora groups. The democratic decline in Turkey fostered a negative perception of the country in the West, and augmented intelligence activities in Europe under the disguise of diaspora engagement policy provoked negative reactions from policy-makers in host countries. This authoritarian descent has reflected in both diaspora policies and the domestic political agenda, especially following the 2016 coup attempt. The same nexus of institutions and non-governmental organizations designed for public diplomacy efforts also sought to facilitate a web for surveilling and monitoring new and old enemies of Turkey. Svante Cornell, a renowned scholar, called this "weaponizing the diaspora."

Turkey notably always has monitored dissident groups abroad closely. In previous political eras, the Kurdish nationalist movement and political Islamists were the enemies of the state. ${ }^{88}$ However, surveillance activities at the time were more discreet and usually operated through diplomatic channels. In Turkey after the coup attempt, these activities became overt, perhaps to incite fear and demonstrate the reach of the state beyond its borders.

\footnotetext{
${ }^{87}$ Cornell ,“Weaponizing” the Diaspora.

${ }^{88}$ Østergaard-Nielsen, The politics of migrants' ; Cornell, “Weaponizing” the Diaspora.
} 
In terms of suppressing Kurdish activism abroad, Turkey still follows familiar tactics such as pressuring host-country governments to ban Kurdish organizations and activism, label Kurdish nationalist movements as terrorists, and prevent them from speaking out after exiting Turkey. In the past, Turkey has asked several European countries to ban Kurdish broadcasting agencies and newspapers. Turkey also used INTERPOL to denounce Kurdish activists as terrorists and ask for their extradition. While this attitude continues under the new diaspora policy, what has changed perhaps is the digital outreach of the state. In the postcoup-attempt political environment, numerous Kurdish, leftist, and Alevi diaspora activists were arrested or detained at Turkish airports when visiting Turkey due to social media posts criticizing Turkish policies or President Erdogan. ${ }^{89}$ However, despite the ongoing criminalization of the Kurds in the transnational space, the AKP appears to prioritize the Gulen Movement, which it has accused of orchestrating the coup, ${ }^{90}$ and perceives it as the primary enemy to eliminate at home and abroad. Now that the Gulen Movement cannot survive within Turkish borders due to an active purge of its members, it must survive in exile. This, however, will not be easy. The YTB and the Diyanet targeted Gulenists abroad using social media and mobilizing on the ground, demonstrating explicitly the extent of the state's national security concerns abroad. ${ }^{91}$ For instance, the YTB's Twitter account tweeted numerous times about the Gulen movement as a terrorist organization in many different languages. Turkey's international Diyanet branches have faced accusations of spying on Gulenists using imams as informants. ${ }^{92}$ Newspapers report that Turkey has filed over a

89. See, for example, https://www.dw.com/en/another-german-citizen-arrested-in-turkey-for-political-reasonsgerman-media/a-49923177, Accessed 3 June 2019.

90. For a detailed analysis on the diasporization of the Gulen movement, see Watmough and Ozturk From 'diaspora by design' to transnational political exile..

${ }^{91}$ Ozturk and Sozeri, Diyanet as a Turkish foreign policy tool.

92. For an example of the discussions regarding imams spying on Turkish dissidents, see "Does Turkey use 'spying imams' to assert its powers abroad?" (2017), accessed on August 30, 2019. https://theconversation.com/does-turkey-use-spying-imams-to-assert-its-powers-abroad-75643. accessed on August 30, 2019 
thousand requests with INTERPOL Red Notices to arrest or extradite Turkish nationals. ${ }^{93}$ More than 600 of these requests ended with denial. ${ }^{94}$ Turkey is heightening its pressure on countries outside of Europe and is focusing especially on Africa, where Gulenists maintain immense academic and commercial networks, to ban their activities. ${ }^{95}$ Some extreme cases include the kidnapping of Gulenists from various countries, including Kosovo. ${ }^{96}$ The task of surveillance is not confined solely to channels of diplomacy or law enforcement. This task also has been subcontracted to loyal diaspora members who gather intelligence and denounce dissidents in the diaspora to the Turkish authorities. These new trends of intimidation directly influence diaspora spaces; they demonstrate clearly how transnational authoritarianism impacts individuals and creates feelings of insecurity and mistrust despite the distance from the homeland. ${ }^{97}$ Self-censorship and withdrawal from activities are proof of this existing repression. ${ }^{98}$ Gulenist communities opt to distance themselves from other Turkish groups. All dissident groups also face legal threats, including the confiscation of passports, the refusal of service at Turkish consulates, and court cases filed against them in Turkey. Even simple actions such as extending visas or providing lawyers with powers of attorney in Turkey are challenging for exiled groups.

Moss theorizes transnational repression under certain categories: lethal retribution, threats, surveillance, exile, withdrawing state benefits, and proxy punishment. ${ }^{99}$ In the case of Turkey, we observe all these categories at varying levels of intensity depending on the

93. https://www.dw.com/en/turkey-using-interpol-to-track-down-dissidents/a-51159723 accessed on August 30, 2019

94. https://stockholmcf.org/interpol-has-rejected-646-red-notice-requests-from-turkey-since-2016-coup-attempt/ accessed on August 30, 2019

95. See, for instance, https://www.alaraby.co.uk/english/news/2018/3/21/senegal-closes-dozens-of-schoolslinked-to-turkeys-gulen accessed on August 30, 2019

96. https://www.haaretz.com/middle-east-news/turkey/.premium-erdogan-s-long-arm-the-turkish-nationalskidnapped-from-europe-1.6428298 accessed on August 30, 2019

${ }^{97}$ Cornell, "Weaponizing” the Diaspora.

${ }_{98}^{98}$ Jorum, Repression across borders, p. 113, Moss, Transnational repression, pp. 480-490.

${ }^{99}$ Moss, Transnational repression, pp. 480-490. 
region, and diaspora management institutions act as repressive state apparatuses when needed. A narrative around the success of Turkey's new diaspora policy accompanies that of Turkey as a rising figure in transnational authoritarian practices. Both negative and positive diaspora engagement practices occur simultaneously, operated by roughly the same governmental and non-governmental actors.

\section{Conclusion}

This article demonstrated that home states can formulate both negative and positive engagement practices with their diasporas under the umbrella of the same diaspora governance policy. State-led diaspora engagement typically emerges in the shadow of the ruling elite's agenda and interests, and the ruling ideology drives its main motivations, whether economic, political, or cultural. Therefore, as we discuss diaspora governance, we also must consider the politics of engagement — a closer scrutiny on domestic politics, foreign policy agendas, and ethnic, ideological, and religious hierarchies in the homeland. In this article, we revealed that public diplomacy and soft power initiatives accompany transnational authoritarian practices, often controlled by the same governmental and non-governmental organizations. Home states can configure diaspora management institutions and networks for their utilization as transnational state apparatuses to advance state interests abroad.

The case of Turkey indicates that policy-makers categorize diasporas as good or bad, loyal or dissident, hostile or useful, and then tailor policies to engage with or disengage from them in a diasporic sphere dominated by home-state narratives. The dominant national narrative that ruling elites create upon forming diaspora governance policies thus answered the questions of who belongs to the diaspora and who is part of the nation. It comes as no surprise that Turkey's diaspora initiatives more often discuss Muslim or Turkic populations in the Middle East or Africa rather than other diaspora groups from Turkey, such as Alevites, 
Kurds, or Armenians. Which citizens state elites consider acceptable determines whether engagement will be negative or positive, thus making diaspora policy and its institutions susceptible to political changes in Turkey. The current policy is undeniably a reflection of the AKP agenda. Its public diplomacy pillar has found little success in Europe but relatively has flourished elsewhere in the world. It actively pursues its pillar of transnational authoritarianism in countries where state authorities feel obliged to suppress the diaspora. The future of Turkey's diaspora policy if the AKP loses an election remains unforeseeable. What is certain, however, is that the potential of the diaspora has received widespread acknowledgement, and its sustained relations are entrenched.

\section{Acknowledgements}

The authors would like to thank Professor Hakan Yavuz for organizing and hosting a one-day workshop on Turkey on April 1, 2019 at the University of Utah at which the first draft of this paper was presented. The authors would also like to thank Professor Eric Hooglund, editor of Middle East Critique, for his careful review of this article. 


\section{References}

Abraham, R. (2012) India and its Diaspora in the Arab Gulf Countries: Tapping into Effective 'Soft Power' and Related Public Diplomacy. In; Diaspora Studies, 5(2), pp. 124146.

Abramson, Y. (2017) Making a homeland, constructing a diaspora: The case of TaglitBirthright Israel. In: Political Geography, 58, pp. 14-23.

Akçapar, Ş. K., \& Aksel, D. B. (2017) Public Diplomacy through Diaspora Engagement: The Case of Turkey. In: Perceptions: Journal of International Affairs, 22(3), pp. 135-160.

Aksel, D. B. (2014) Kins, distant workers, diasporas: constructing Turkey's transnational members abroad. In: Turkish Studies, 15(2), pp. 195-219.

Althusser, L. (2006) Ideology and ideological state apparatuses (notes towards an investigation). In: The anthropology of the state: A reader, 9(1), pp. 86-98.

Aydin, Y. (2014) "The New Turkish Diaspora Policy: Its Aims, Their Limits and the Challenges for Associations of People of Turkish Origin and Decision-makers in Germany." In: $\quad$ SWP $\quad$ Research Paper. Available online at: https://www.academia.edu/9387459/The_New_Turkish_Diaspora_Policy . Accessed March 1, 2019. 
Barr, M. (2012) Nation branding as nation building: China's image campaign. In: East Asia, 29(1), pp. 81-94.

Baser, B. (2017) Turkey's Ever-Evolving Attitude-Shift Towards Engagement with Its Diaspora. In: Emigration and Diaspora Policies in the Age of Mobility, pp. 221-238 (PLACE OF PUBLICATION???: Springer, Cham).

Baser, B., \& Öztürk, A. E. (2017) Authoritarian politics in Turkey: Elections, resistance and the AKP (London: Bloomsbury Publishing).

Brand, L. A. (2002) States and their expatriates: Explaining the development of Tunisian and Moroccan emigration-related institutions. Working Paper (University of Southern California).

Brand, L. A. (2006) Citizens abroad: Emigration and the state in the Middle East and North Africa, Vol. 23 (Cambridge, UK: Cambridge University Press).

Brand, L. A. (2010) Authoritarian states and voting from abroad: North African experiences. In: Comparative Politics, 43(1), pp. 81-99.

Brand, L. A. (2017) State, citizenship, and diaspora: The cases of Jordan and Lebanon, Working Paper No. 146 (University of California, San Diego). 
Cooley, A. \& Heathershaw, J. (2017) Dictators without borders: Power and money in Central Asia (New Haven: Yale University Press).

Cornell, S. (2017) "Weaponizing” the Diaspora: Erdogan and the Turks in Europe. In: Turkey Analyst. Available online at: https://www.turkeyanalyst.org/publications/turkey-analystarticles/item/579-weaponizing-the-diaspora-erdo\%C4\%9Fan-and-the-turks-in-europe.html. Accessed: 18 September 2019.

Délano, A. (2014) The diffusion of diaspora engagement policies: A Latin American agenda. In: Political Geography, 41, pp. 90-100.

Délano, A. \& Gamlen, A. (2014) Comparing and theorizing state-diaspora relations. In: Political Geography, 41, pp. 43-53.

Fan, Y. (2006) Branding the nation: What is being branded? In: Journal of vacation marketing, 12(1), pp. 5-14.

Gamlen, A. (2008) Why engage diasporas? ESRC Centre on Migration, Policy and Society, Working Paper No. 63, (Oxford: University of Oxford).

Glasius, M. (2018) Extraterritorial authoritarian practices: a framework. In: Globalizations, 15(2), pp. 179-197. 
Hirt, N. \& Saleh Mohammad, A. (2018) By way of patriotism, coercion, or instrumentalization: How the Eritrean regime makes use of the diaspora to stabilize its rule. In: Globalizations, 15(2), pp. 232-247.

Ho, E. L. E. (2011) 'Claiming' the diaspora: Elite mobility, sending state strategies and the spatialities of citizenship. In: Progress in Human Geography, 35(6), pp. 757-772.

Jorum, E. L. (2015) Repression across borders: Homeland response to anti-regime mobilization among Syrians in Sweden. In: Diaspora Studies, 8(2), pp. 104-119.

Kuradusenge, C. (2016) Denied Victimhood and Contested Narratives: The Case of Hutu Diaspora. In: Genocide Studies and Prevention: An International Journal, 10(2), pp. 59-75

Levitt, P. \& De la Dehesa, R. (2003) Transnational migration and the redefinition of the state: Variations and explanations. In: Ethnic and racial studies, 26(4), pp. 587-611.

Lewis, D. (2015) “Illiberal Spaces:” Uzbekistan's extraterritorial security practices and the spatial politics of contemporary authoritarianism. In: Nationalities Papers, 43(1), pp. 140159.

Li, H. (2012) The Chinese Diaspora and China's Public Diplomacy: Contentious Politics for the Beijing Olympic Float. In: International Journal of Communication, 6, pp. 2245-2279.

Liu, H. \& Van Dongen, E. (2016) China's diaspora policies as a new mode of transnational governance. In: Journal of Contemporary China, 25(102), pp. 805-821. 
Mencutek, Z. S. \& Baser, B. (2018) Mobilizing Diasporas: Insights from Turkey's Attempts to Reach Turkish Citizens Abroad. In: Journal of Balkan and Near Eastern Studies, 20(1), pp. 86-105.

Moss, D. M. (2016) Transnational repression, diaspora mobilization, and the case of the Arab Spring. In: Social Problems, 63(4), pp. 480-498.

Murti, B. \& Zaharna, R. S. (2014) India's Digital Diaspora Diplomacy: Operationalizing Collaborative Public Diplomacy Strategies for Social Media In: Exchange: The Journal of Public Diplomacy, 5(1), p. 3-27.

Mylonas, H. (2013) The politics of diaspora management in the republic of Korea. In: The Asian Institute for Policy Studies, 81, pp. 1-12.

Okyay, A. S. (2015) Diaspora-making as a state-led project: Turkey's expansive diaspora strategy and its implications for emigrant and kin populations. PhD dissertation, European University Institute, Florence, Italy.

Østergaard-Nielsen, E. (2003) The politics of migrants' transnational political practices. In: International migration review, 37(3), pp. 760-786.

Öztürk, A. E. \& Sözeri, S. (2018) Diyanet as a Turkish foreign policy tool: Evidence from the Netherlands and Bulgaria. In: Politics and Religion, 11(3), pp. 624-648. 
Öztürk, A. E. \& Tas. H. (2020) The Repertoire of Extraterritorial Repression: Diasporas and Home StateS. In: Migration Letters 17 (1), pp. 59-69.

Ragazzi, F. (2014) A comparative analysis of diaspora policies. In: Political Geography, 41, pp. 74-89.

Stone, D. \& Douglas, E. (2018) Advance diaspora diplomacy in a networked world. In: International Journal of Cultural Policy, 24(6), pp. 710-723.

Tsourapas, G. (2015) Why do states develop multi-tier emigrant policies? Evidence from Egypt. In: Journal of Ethnic and Migration Studies, 41(13), pp. 2192-2214.

Tsourapas, G. (2018) Authoritarian emigration states: Soft power and cross-border mobility in the Middle East. In: International Political Science Review, 39(3), pp. 400-416.

Turner, S. (2013) Staging the Rwandan diaspora: The politics of performance. In: African Studies, 72(2), pp. 265-284.

Ünver, C. (2013) Changing diaspora politics of Turkey and public diplomacy. In: Turkish Policy Quarterly, 12(1), pp. 181-189.

Watmough, S. P. \& Öztürk, A. E. (2018) From 'diaspora by design' to transnational political exile: the Gülen Movement in transition. In: Politics, Religion \& Ideology, 19(1), pp. 33-52. 
Yaldiz, F. (2019) A Critical Approach to the Term Turkish Diaspora: Is there 'the' Turkish Diaspora? In: Bilig, (91), pp. 53-80.

Yanasmayan, Z. \& Kaşlı, Z. (2019) Reading diasporic engagements through the lens of citizenship: Turkey as a test case. In: Political Geography, 70, pp. 24-33.

Yavuz, M. H. (ed.) (2006) The Emergence of a New Turkey: Islam, Democracy, and the AK Party (Salt Lake City: University of Utah Press). 